\title{
EVOLUTION OF LATE WINTER TIME THERMALLY DRIVEN LOCAL FLOWS AND TEMPERATURE FIELDS OVER FAR-WESTERN NEPAL
}

\section{Ram P. Regmi and Sangeeta Maharjan}

Journal of Institute of Science and Technology

Volume 21, Issue 1, August 2016

ISSN: 2469-9062 (print), 2467-9240(e)

Editors:

Prof. Dr. Kumar Sapkota

Prof. Dr. Armila Rajbhandari

Assoc. Prof. Dr. Gopi Chandra Kaphle

JIST, 21 (1), 35-47 (2016)

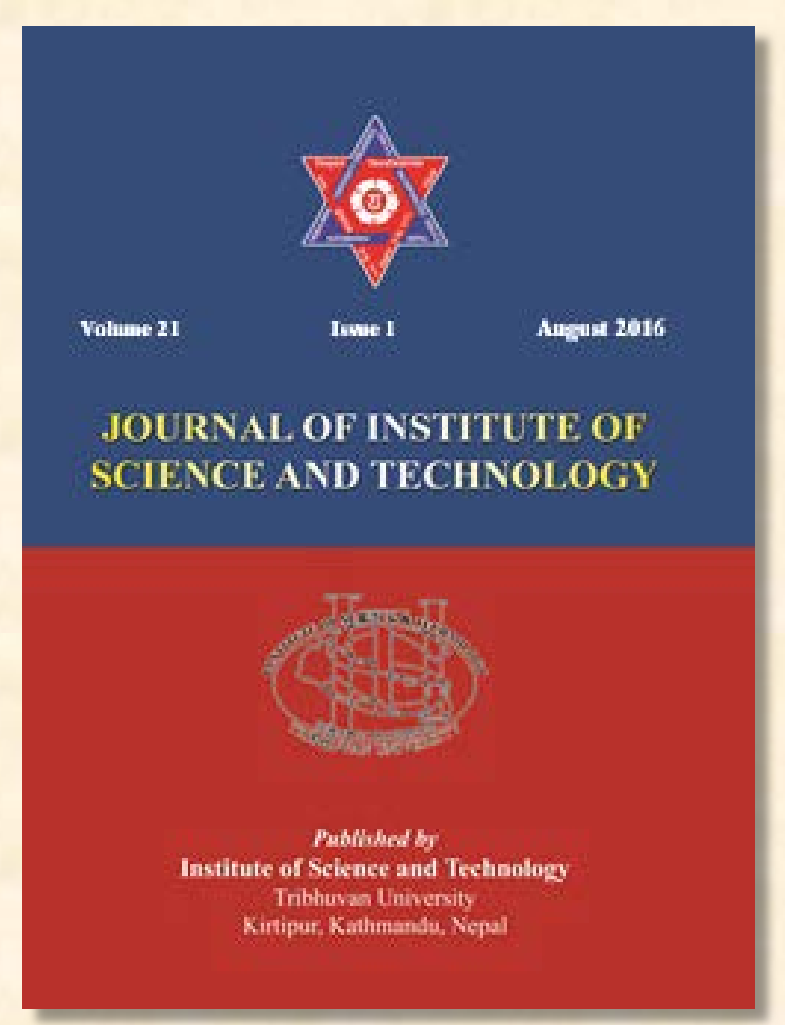

Published by:

Institute of Science and Technology

Tribhuvan University

Kirtipur, Kathmandu, Nepal 


\title{
EVOLUTION OF LATE WINTERTIME THERMALLY DRIVEN LOCAL FLOWS AND TEMPERATURE FIELDS OVER FAR-WESTERN NEPAL
}

\author{
Ram P. Regmi* and Sangeeta Maharjan \\ National Atmospheric Resource and Environmental Research Laboratory (NARERL) \\ Central Department of Physics, Tribhuvan University, Kirtipur, Nepal \\ Corresponding email: ram.p.regmi@gmail.com
}

\begin{abstract}
Atmospheric processes over the Himalayan complex terrain are yet to be studied extensively. Only a few significant researches are reported from this region and the Far-Western Region (FWR) of Nepal still remains untouched. Thus, the present study was conceived to understand the meteorological flow characteristics and thermal environment over the region and associated areas during the late wintertime with the application of the state-of-the-art-of Weather Research and Forecasting (WRF) Modeling System. The study revealed that the northern mountainous region developed strong down slope wind during the night and morning times, which sweeps out the southern plain area of Nepal and may reach just beyond the border. The wind over the plain was very shallow whose depth was just about $100 \mathrm{~m}$. The down slope winds over the southern slope of the Daijee and Nandhaur mountain ranges were significantly enhanced by the subsidence of the southerly wind that prevails above $1 \mathrm{~km}$ height above the mean sea level. Close to the noon time a very gentle southerly valley wind from the southern plain replaced the nighttime down slope. Very shallow but strong surface inversion builds up over the plain that breaks up in the late morning. The depth of the mixed layer and the valley wind may reach up to $1 \mathrm{~km}$ in the afternoon. The thermal environment over the FWR of Nepal was fairly hot that may remain around $35^{\circ} \mathrm{C}$ in the afternoon around the Mahendranagar area whereas the temperature during the nighttime may go as low as $23^{\circ} \mathrm{C}$. The study revealed that, contrary to the general perception, temperature over plain areas of Nepal was significantly higher than further southern areas belonging to India. The meteorological flow fields over the FWR of Nepal executed diurnal periodicity with little day-to-day variation during the late wintertime.
\end{abstract}

Keywords: Atmospheric modeling, Mountain wind, Thermal environment, Boundary layer, Far-Western Nepal

\section{INTRODUCTION}

The Himalayan region is of fundamental importance to the prevailing weather and climate in the south and central Asia if not for the whole world. The region captures almost all types of climate that exist on the earth and provides an unparallel pool of genetic resources and biodiversity (Chalise, 1993). Multiplicity of the diverse local climate is caused by interaction of different atmospheric processes such as local heat budget, thermal circulations, and convection and advection as a result of synoptic process. In recent decades, the Himalayan weather and climate have been undergoing rapid transformations in the warming world. A slight perturbation in the prevailing delicate weather systems and hence the climate can bring significant adverse effects. Small changes of water availability, floods, drought and late frosts can have drastic effects on agricultural economy of the region.

Despite all these importance and foreseen consequences, weather and climate over the Himalayas and associated areas have not been extensively studied, particularly, over the extreme terrains of Nepal Himalaya. Very few research findings on the characteristics of weather and climatic systems that prevail over extreme terrains of Himalaya and areas closely associated to it are reported. The few research reports may include Ohata et al. (2001) on the mountain valley wind in the Khumbu Himal, Zangal et al. (2001) discussed the diurnal wind system in the Himalayan Kaligandaki valley, Regmi et al. (2003) examined the late wintertime 
local flows over the Kathmandu valley, Zhou et al. (2008) showed the impact of South Asian Monsoon on the northern slope of Mt. Everest. Dynamics of glacier winds on Rongbuk Valley, north of Mount Everest has been well discussed by Song et al. (2007) and aviation weather hazards over Jomsom Airport by Regmi (2014).

The Middle Hills are the integral part of the Himalayas and the Ganges Plain. It is speculated that the Middle Hill region might have been playing a major role for the transfer of both natural and anthropogenic weather and climatic forcers in between high Himalayas and the Ganges Plain. Detail knowledge of meteorological flow characteristics over the Middle Hills of Nepal Himalaya are desired to understand the cause and consequences of environmental, weather and climatic transformations and hence to develop necessary adaptation policies. It also helps understand fire weather pattern and hence to manage wild fires (Janice et al., 2013) as well.

As part of the ongoing researches in characterizing the meteorological flow characteristics over the Middle Hills of Nepal Himalaya at NARERL, present study was conceived to understand the local wind circulations and the distribution of temperature over FWR of Nepal and associated areas beyond the border.

Growing urbanization and industrialization over the closely associated areas of India is also of serious concern as they could be an acute and constant source of air pollution deposition over FWR and over the Himalayas. The thermally driven local wind circulations over the area can have important role to transport pollutants from southern plain area towards Nepal and up into the northern mountainous areas. However, the characteristics of the thermally driven local wind circulation over FWR, bestowed with majestic natural beauty and rich cultures but, so far, lagged much behind with respect to modern development activities, are still untouched. Present study was thus conceived to understand the temporal evolution and spatial distribution of thermally driven local wind circulations and temperature over FWR during the late wintertime with the application of regional scale numerical modeling system.

\section{METHOLODGY}

The temporal evolution and spatial distributions of local wind system and temperature over the FWR has been numerically simulated using the
Weather Research and Forecasting (WRF) Modeling System. The WRF model (Michalakes et al., 1998, 2001) is a next-generation mesoscale numerical weather prediction system designed to serve both atmospheric research and operational forecasting needs. The WRF system has been extensively used in downscaling weather and climate at the scales from one kilometer to thousands of kilometers. Detail description of WRF is available elsewhere (Skamarock et al., 2008). The WRF Modeling System has been successfully implemented over the complex terrain of Nepal Himalayas for various purposes. Example may include the study of wind energy potential for Middle Hills of Nepal Himalaya (Regmi \& Maharjan, 2013a, Regmi \& Maharjan, 2013b), aviation weather hazards over an extreme airport, the Jomsom Airport (Regmi 2014a) and Himalayan foothills in Western Nepal (Regmi 2014b), meteorological flow fields of over different parts of Nepal (Maharjan 2014, Maharjan \& Regmi 2014, Acharya et al. 2014).

For this study we used a triply nested two-way interacting mesh of calculation domains. WRF Modeling System was configured with three domains having horizontal grid spacing of 9, 3 and $1 \mathrm{~km}$ for the coarse (D01), fine (D02) and the finest (D03) domains, respectively (Fig. 1a). The domains D01 and D02 have $52 \times 52$ grid points and the D03 has $70 \times 70$ grid points with each having 35 vertical levels. The model top was set at $10 \mathrm{hPa}$. All of these domains were centered at Mahendranagar Bazaar (MB), FWR, Nepal.

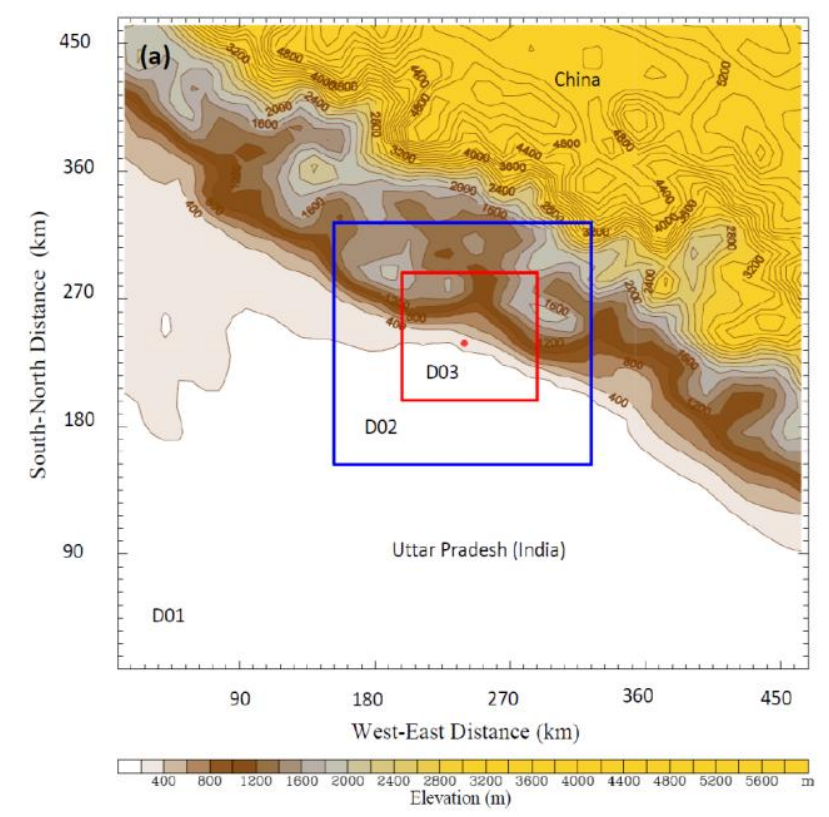




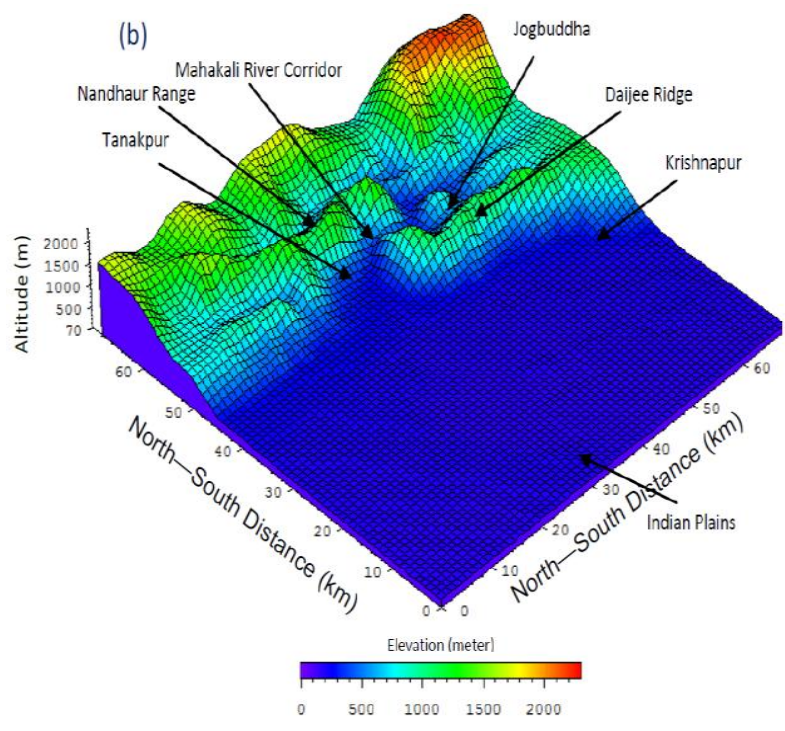

Fig. 1. (a) A triply nested domains showing its area coverage and all centered at Mahendranagar Bazaar (orange point) of FWR, Nepal. Blue squared box and red squared box represent the area of fine domain (D02) and the finest domain (D03), respectively. (b) 3D-topographic view of finest domain and its immediate surroundings.

Thompson graupel scheme for microphysics, RRTM scheme for longwave radiation, Dudhia scheme for shortwave radiation, YSU scheme for planetary boundary layer, and the Noah landsurface model have been used for the simulation. Moreover, the Kain-Fritsch cumulus scheme was turned on only for the outermost domain. Incorporating the 24 categories land-use and 30 second terrain elevation data by United States Geological Survey (USGS), the model was initialized with $1^{\circ} \times 1^{\circ} \mathrm{NCEP} / \mathrm{FNL}$ meteorological inputs. A weeklong simulation from 13 March 2013 to 19 March 2013 was carried out in which first 24 hours simulated data was discarded as a spin-up period of model calculation and data for the rest of the days were retained for further investigation in reference to the findings of Jiménez and Dudhia (2012).

\section{RESULTS AND DISCUSSION}

Examining the diurnal variation and spatial distributions of predicted near surface wind circulations and temperature over the area enclosed by the finest domain for week long period during 13 to19 March 2013, we observed that the local wind system and temperature distribution exhibit diurnal periodicity, i.e., local wind system and temperature distribution repeated everyday with little day-to-day variation during the late winter season. Hence, we describe the temporal evolution and spatial distribution of local wind circulations and temperature over the area by considering the day of 15 March 2013 as the representative day of late wintertime over the FWR.

\section{A. Near Surface Wind Fields}

In this section, we will discuss the diurnal variation and spatial distribution of near surface wind circulations over the FWR of Nepal and adjoining Indian areas in the south and the west as well as explore the possible connection between the local circulations within and beyond the border. Fig. 2 illustrates the diurnal characteristics of local wind system over the region at about 30 meters above the ground level. During the midnight 15 March 2013, well developed down slope winds prevailed over the northern mountainous region, which strengthen further as the morning of 15 March 2013 progressed. These down slope winds together with the drainage flow along the Mahakali River gorge appeared to influence the significant portion of the southern plain (Fig. 2a). The mountainous areas of India develop northerly down slope wind that is blocked by the northeasterly drainage flow flushing out from the mouth of the Mahakali River gorge and does not intrude into Nepal area. The northeasterly down slope wind over the northeastern mountainous area sharply vanished along the southeast-northwest line that passed little south to Krishnapur (Fig. 1b for location) indicating that the wind must have been lifted up and flows over the stratified shallow layer over the plain (Regmi et al., 2003). The flow field along the Mahakali River gorge and over the mountain range west to Daijee along the southwest-northeast line passing through Mahendranagar is very complex. Along the Mahakali River gorge, the drainage wind appeared to be enhanced by the downslope winds over the two adjacent hill slopes, namely, Daijee and Nandhaur Range, which flushed over the plain at Tanakpur (see Fig. 1b for location). The drainage flow along the Mahakali River gorge north to Jogbudha also appeared to vanish sharply before reaching Jogbudha area and an enhanced flow appeared over the southern slope of Daijee mountain range that may cross southern border of Nepal developing a rather weak northwesterly flow in the Indian side. Over the northern slope of Daijee range, southerly wind prevails that appears to block the drainage flow. 

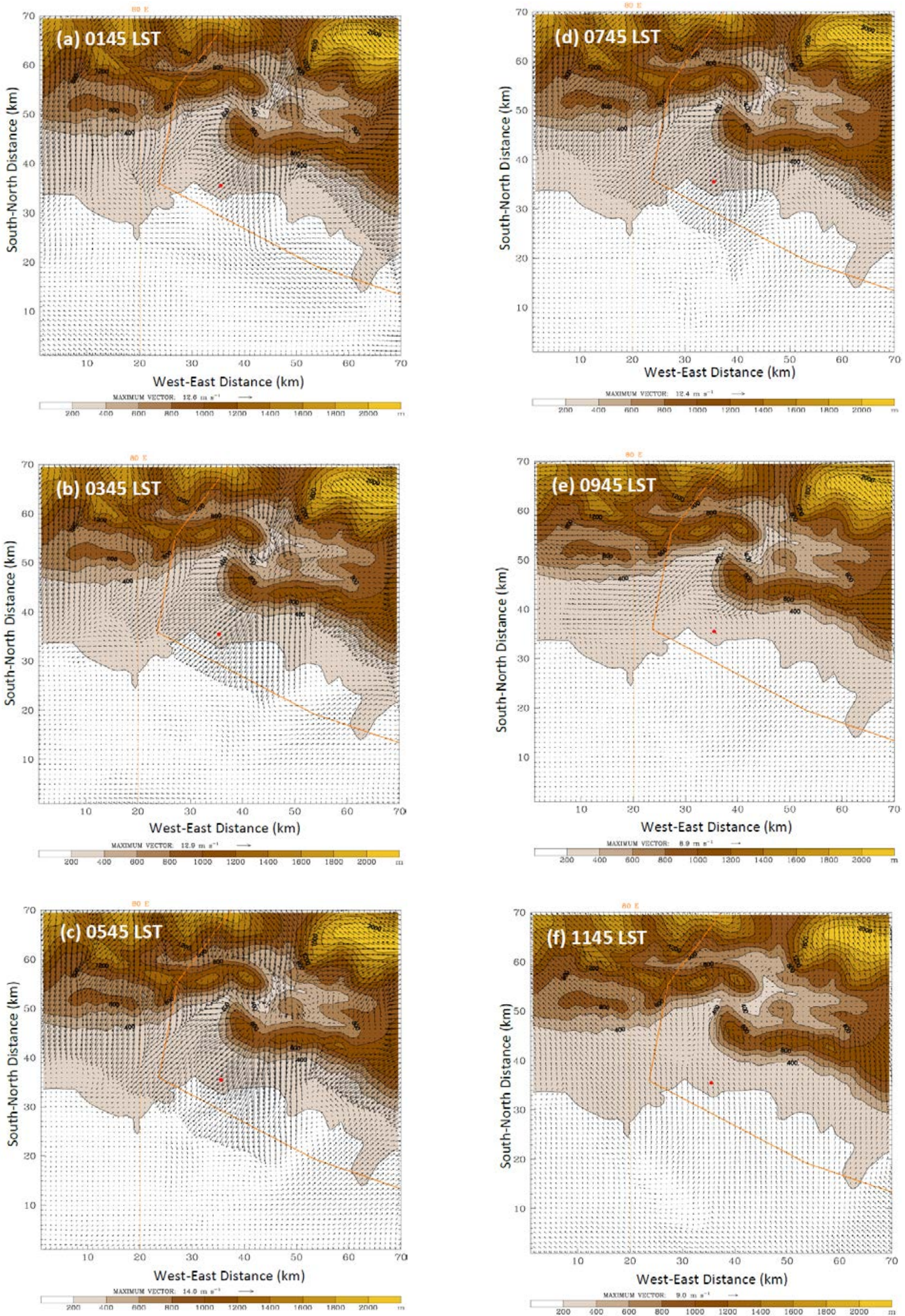

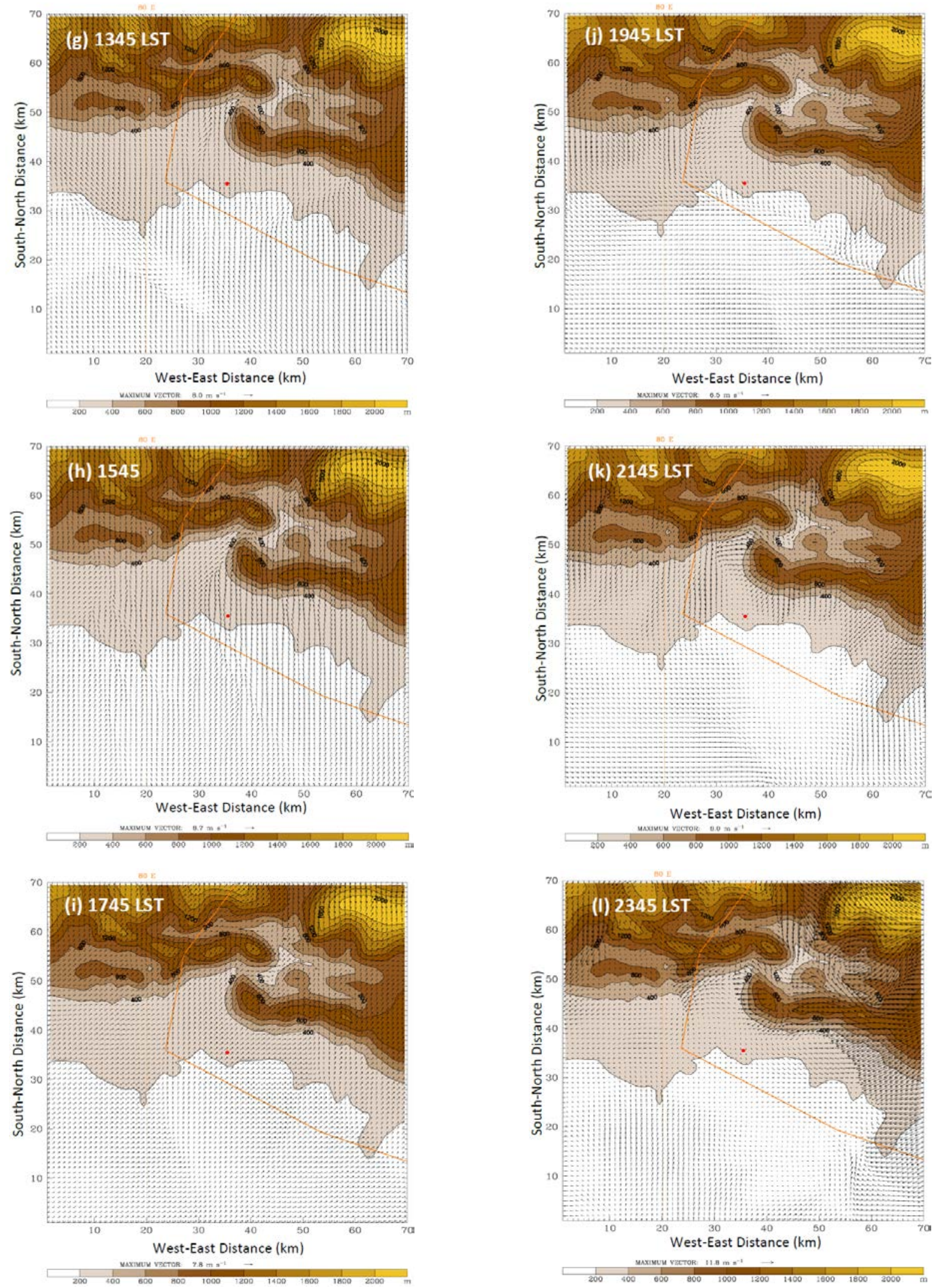

Fig.2. The spatial and temporal distribution of flow fields superimposed with terrain contours (at the interval of 200 meters) over Far-Western Region and its immediate surrounding areas at time interval of two hours in Local Standard Time (LST) format. Thick solid orange line represents Nepal-India border and dotted orange straight line is $80^{\circ} \mathrm{E}$ longitude line. 
The sharply vanishing northerly drainage flow, enhanced flow over the southern slope of Daijee range and reverse flow in between suggest that the drainage flow along the Mahakali River gorge is making a hydraulic jump like flow over the area around Jogbudha and lifts up to strike over Daijee ridge line enhancing the down slope wind in the southern slope. This point will be discussed further in the next subsection. This particular local flow pattern may continue to persist till the late morning except the down slope wind from the Nepal mountainous area may penetrate deep into the Indian area, the weak northwesterly flow close to the southern border in the Indian side vanishes and southwesterly moderate wind from Indian area may intrude into Nepal in the Kirshnapur area. The maximum down slope wind speed over the region appeared $14.3 \mathrm{~ms}^{-1}$ (Fig. 2b-d). However, by the sunrise time, these down slope started to weaken and are gradually replaced by gentle up valley wind from the southern plain and the upslope wind over the ridges (Fig. 2e-f).

The Mahakali River Basin around Jogbudha appeared to be calm close to the noontime, which was later feed by the southerly valley wind, channeled into the basin via Tanakpur and low mountain passes of Daijee range. The flow pattern continued until the late afternoon (Fig. 2g-i) with minor changes such as the southerly valley wind became rather southwesterly during the late afternoon time. By sunset time, the mountainous region appeared to initiate again the downslope winds in their slopes (Fig. 2j) that converge with the valley winds from the plain along the southeast-northwest line very close to the southern border. The flow system over the region gradually returned to the midnight situation described earlier (Fig. 2a, k-1) exhibiting a diurnal periodicity.

\section{B. Vertical structure of wind and potential temperature}

In this sub-section, we will discuss the vertical structure of wind and potential temperature over the FWR. Fig. 3 shows the vertical cross-sectional plots of potential temperature, horizontal wind vectors and the vertical winds at various times along the southwest-northeast line that passes through the Mahendranagar Municipality in FWR of Nepal.

During the midnight of 15 March 2013, the distribution of the potential temperature (figure not shown) contour suggests that strong but very shallow inversion layer develops over the southern plain including Mahendranagar Municipality and further southern area beyond the border. The immediate atmosphere over the Mahakali Basin around and north to the Jogbudha was also significantly stratified. Very strong southwesterly wind of more than $20 \mathrm{~ms}^{-1}$ prevailed in the upper level that gradually decreased down to the calm situation below $1 \mathrm{~km}$ above the ground. The wind in between $1 \mathrm{~km}$ and $3 \mathrm{~km}$ appeared rather mild and was less than $10 \mathrm{~ms}^{-1}$ and the lower portion of which make subsidence over the southern slope of the Daijee mountain range north to Mahendranagar reinforcing the downslope wind over the slope. The downslope wind or drainage wind from the northern mountainous area over the Mahakali Basin around and north to Jogbudha area appeared rather weak but swept the basin and tend to climb over the Daijee ridge. The flow system, particularly the drainage wind from the north quickly strengthened as the morning feeding the down slope wind over the southern slope of the Daijee range of 15 March 2013 progressed (Fig. 3a).

The overturning contours of potential temperature over the southern slope of the Daijee range as well as over the plain adjacent to the range suggest that the downslope wind might have been making hydraulic jump as well. Over the Mahakali Basin around Jogbudha, the distribution of potential temperature contours, their nature and the alternate updraft and downdrafts suggest that trapped waves might have formed over the basin during the period. While retaining the basic pattern of the flow fields, the massive scale subsidence from the southerly wind layer in between $1 \mathrm{~km}$ to $3 \mathrm{~km}$ occured over the southern slope of the Daijee range in the early morning (Fig. 3b) that deeply penetrated the southern plain. Interesting enough, the flow over southern plain was very shallow of about 100 meters in its depth. Strong but very shallow surface inversion developed over the plain during the period. In the morning close to the sunrise time, the subsidence over the southern slope of Daijee range weakened but the drainage flow over the Mahakali basin around the Jogbudha retained the same features as in the early morning time (Fig. 3c).

This particular situation may continue till the late morning except the southerly layer of wind in between $1 \mathrm{~km}$ and $3 \mathrm{~km}$ height, near surface flow over the southern plain and the surface inversion vanish. The drainage flow over the Mahakali Basin around Jogbudha significantly weakened (Fig. 3d- 
e). Close to the noontime (Fig. 3f), the mixed layer over Mahendranagar area may develop up to 1.5 $\mathrm{km}$ above the ground and very weak southerly wind prevailed over the area. Over the southern slope of the Daijee range, the upslope wind developed that contribute to the significant updraft above the Daijee range ridge top whereas over the Mahakali Basin around Jogbudha received a subsidence of magnitude more than $77 \mathrm{cms}^{-1}$. In the afternoon (Fig. 3g-h), gentle but deep southerly valley wind developed over the plain that feeds the northern mountainous area of FWR of Nepal which may bring atmospheric pollutants up above the Middle Hills and to the high Himalayas. The mixed height over the plain may develop up to the height of $3 \mathrm{~km}$ above the ground, which is capped by rather stratified layer aloft and hence the pollutants released over the plain area of Nepal and India disperse vertically up to this height. Note the enhancement of valley wind over the southern slopes of Himalayan foothills and Middle Hills and downdraft in the northern slopes.

The flow pattern may continue with little change in the strength and depth of the valley wind until early evening (Fig. 3h-i). In the evening (Fig. 3j), the thermally driven valley wind vanished, shallow surface inversion developed over the southern plain and the northern slopes of the Daijee range developed downslope wind but southern slopes were yet to develop significant downslope wind and gradually return to the situation described earlier for midnight (Fig. 3k-1). The vertical crosssectional distribution of wind and potential temperature also reveals the diurnal periodicity of flow system during the season.

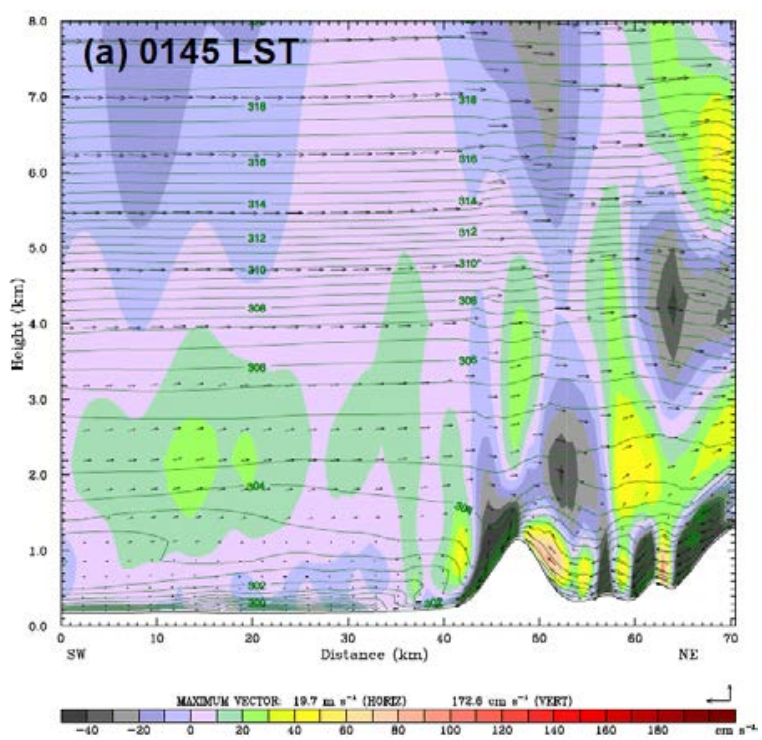

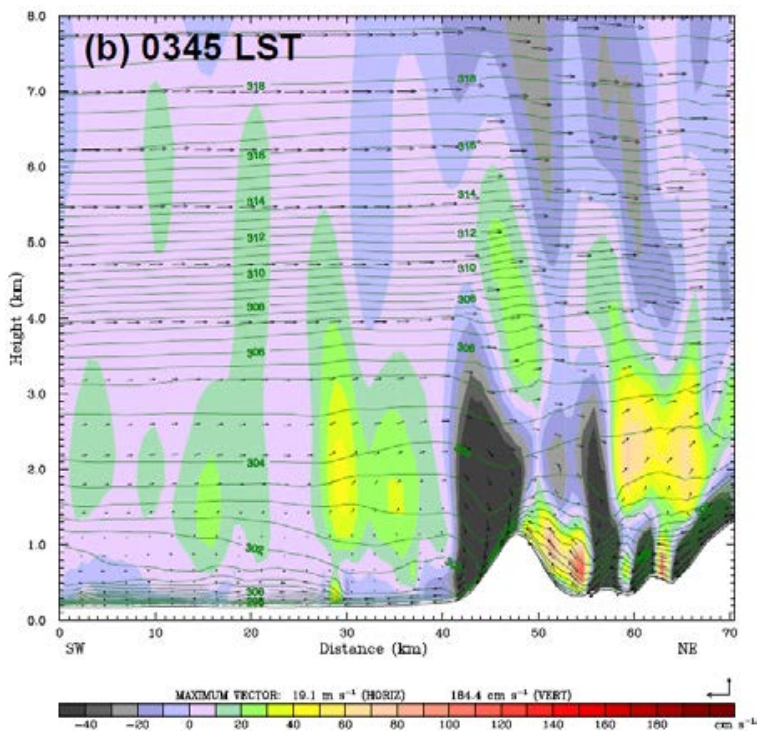
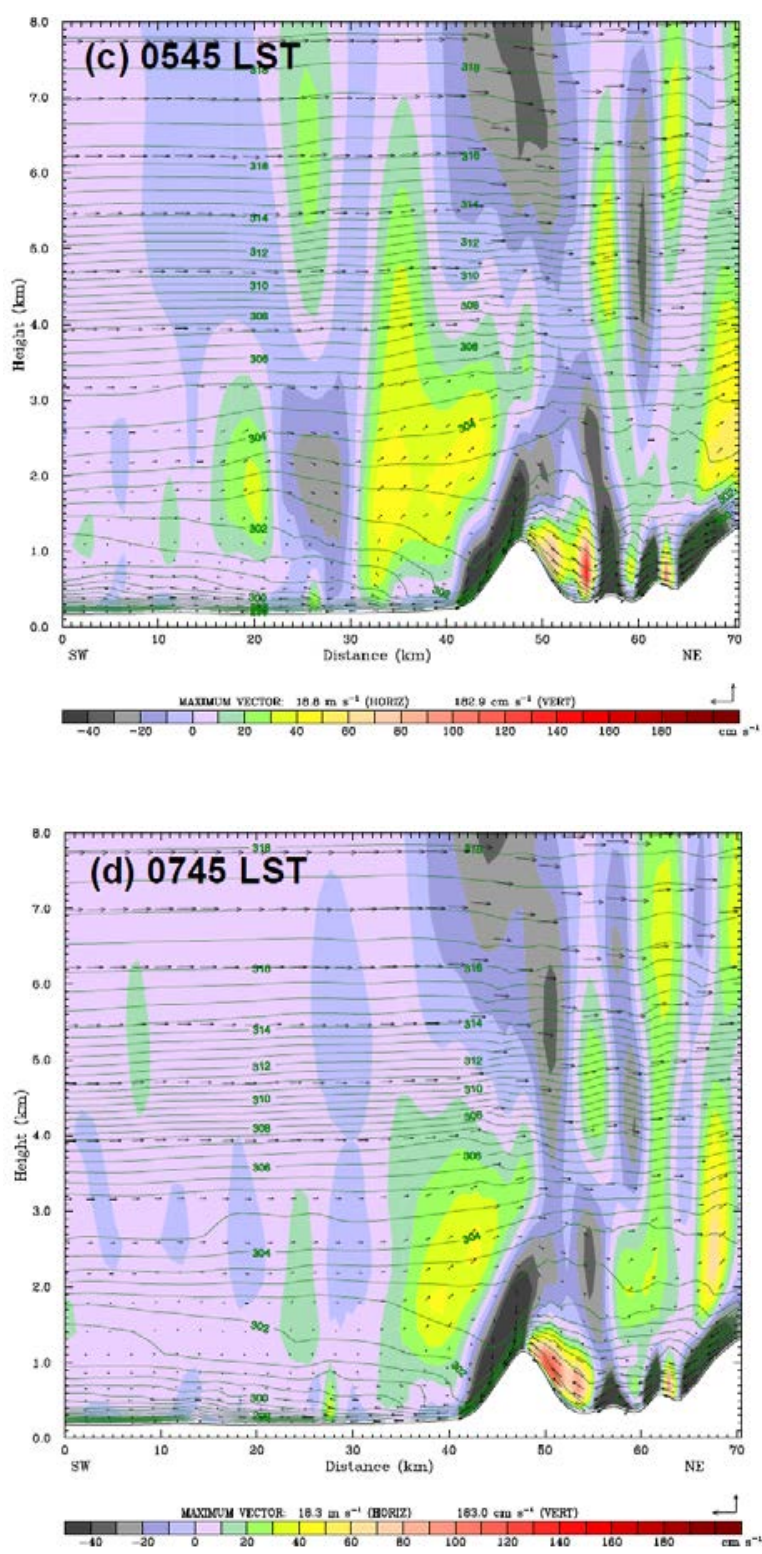

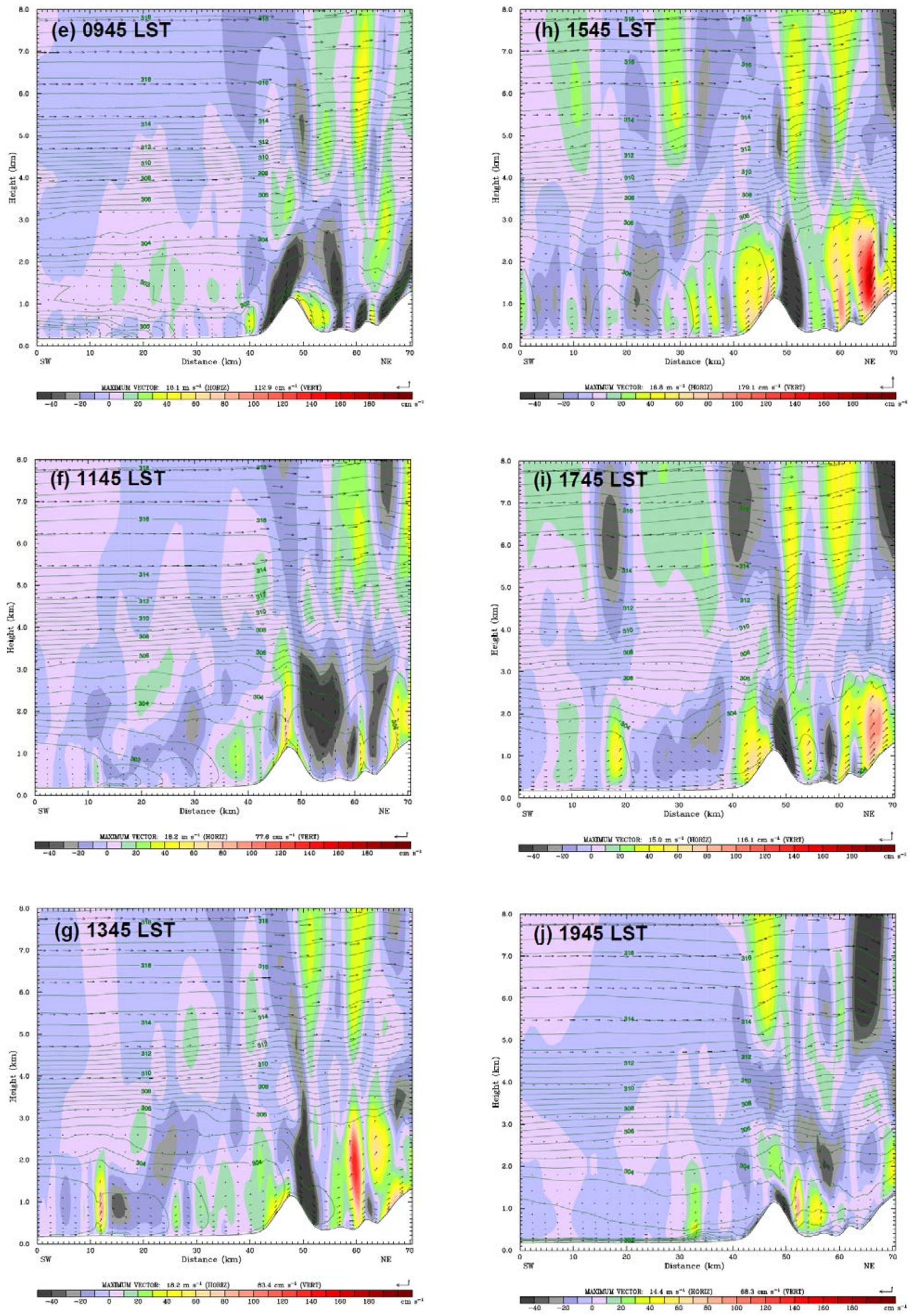

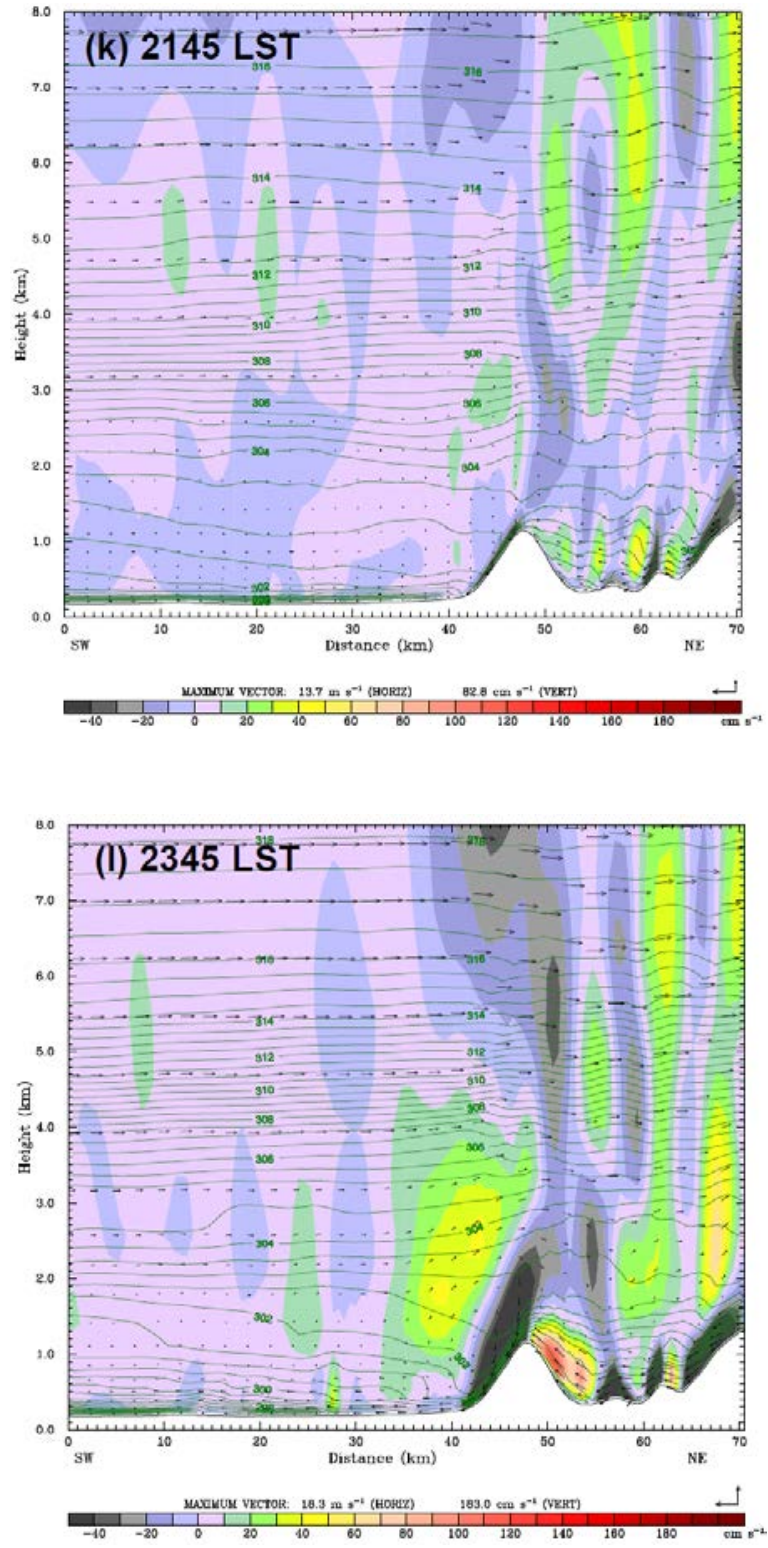

Fig. 3. Vertical cross-sectional plots of horizontal wind (vectors), potential temperature (contours) and vertical wind (raster) along the southwestnortheast line passing through the

Mahendranagar Municipality in FWR illustrating the evolution of mixed layer, vertical structure of wind and potential temperature..

\section{Distribution of temperature fields}

Fig. 4. illustrates the diurnal variation and spatial distribution of near surface temperature over finest domain (D03) during day of 15 March 2013 under fair weather conditions. During the midnight of 15 March 2013, the near surface temperature (figure not shown) over the north most mountainous areas may go below $16^{\circ} \mathrm{C}$, which gradually increases over the foothills and mountainous low lands. The temperature over the Mahakali River Basin northwest to the Jogbudha area may reach up to $27^{\circ} \mathrm{C}$. However, over the Daijee and Nandhaur mountain ridges hold temperature at about $17^{\circ} \mathrm{C}$. It is interesting to note that over the southern plain areas adjacent to the lees of Daijee and Nandhaur ranges and the eastern plain area appeared to hold the highest temperature that may reach up to $28^{\circ} \mathrm{C}$. The large plain areas south and east to Mahendranagar Municipality possessed comparatively lower temperature of about $17^{\circ} \mathrm{C}$. As the morning of 15 March 2013 progressed, the near surface temperature distribution over the north most mountainous areas, the Mahakali River Basin, Daijee and Nandhaur ridges as well as over the plain adjacent to the lee of Nandhaur range appeared to be slightly decreasing. However, the temperature over the Mahendranagar Municipality area and the adjoining northwest and southeast areas appeared to have significantly increased to about $27^{\circ} \mathrm{C}$ (Fig. 4a).

In the early morning (Fig. $4 \mathrm{~b}-\mathrm{c}$ ), the relatively higher temperature in and around the Mahendranagar and over the areas close to the lees of Daijee and Nandhaur ridges significantly decreased, possibly due to the penetration of northerly downslope wind but the temperature over the southern area beyond the border appeared to increase. The distribution of temperature over the plain suggests that areas adjacent to the lees of Daijee and Nandhaur ranges are, in particular significantly warmer compared to the areas beyond the border.

After sunrise (Fig. 4d), appreciable changes was seen in the distribution of temperature over the southern plain. Along the Mahakali River corridor, eastern area around Krishnapur area became relatively cooler and the area around Mahendranagar and associated areas hold the maximum temperature. The difference between the temperature around Mahendranagar and the Kirshnapur area appeared to be as much as 6 to $10^{\circ} \mathrm{C}$. In the late morning (Fig. 4e), the temperature over areas in and around the Mahendranagar, particularly, areas northwest to it may reach to about $29^{\circ} \mathrm{C}$. The eastern plain area of Nepal east to Mahendranagar and southern part of Mahakali Basin northeast to Jogbudha appeared relatively cooler where the temperature may prevail around $26^{\circ} \mathrm{C}$. The temperature over the southern plain area beyond the border may vary from 18 to $26^{\circ} \mathrm{C}$. Close to the noontime (Fig. 4f), southern plain within 
Nepal including Mahendranagar hold a uniform temperature of about $30^{\circ} \mathrm{C}$ but the eastern edge of the plain may have $32^{\circ} \mathrm{C}$. It is interesting to note that the temperature over southwestern Indian plain area appeared to be as low as $25^{\circ} \mathrm{C}$. In the afternoon (Fig. 4g-h), the temperature over the whole plain area of Nepal east to Mahendranagar may increase to about $34^{\circ} \mathrm{C}$ and over rest of the plain area of Nepal and India including the low land area of Mahakali Basin may uniformly attain $30^{\circ} \mathrm{C}$.

The temperature over Daijee and Nandhaur ranges varied from 25 to $18^{\circ} \mathrm{C}$ depending upon height. The minimum temperature appeared over the northeastern mountaintop, which was less than $15^{\circ} \mathrm{C}$. In the late afternoon (Fig. $4 \mathrm{i}$ ), the whole plain area of Nepal and India hold a uniform temperature of about $29^{\circ} \mathrm{C}$ whereas areas immediate south to Mahendranagar, southeastern areas of Nepal may possessed a degree higher temperature. As the evening progressed, the overall temperature gradually decreased and smoothly returned to the pattern described earlier for midnight time (Fig.4j-1).

It is interesting to note that, contrary to the general perception of prevalence of higher temperature over more southern part of the Ganges Plain compared to the northern part, the distribution of temperature shows that the plain area of FWR of Nepal is warmer than the areas beyond the border. Considering the wind circulation pattern and the temperature distribution pattern, it can be said that the local wind circulations over the region during late wintertime under fair weather conditions are basically driven by the thermal gradients.

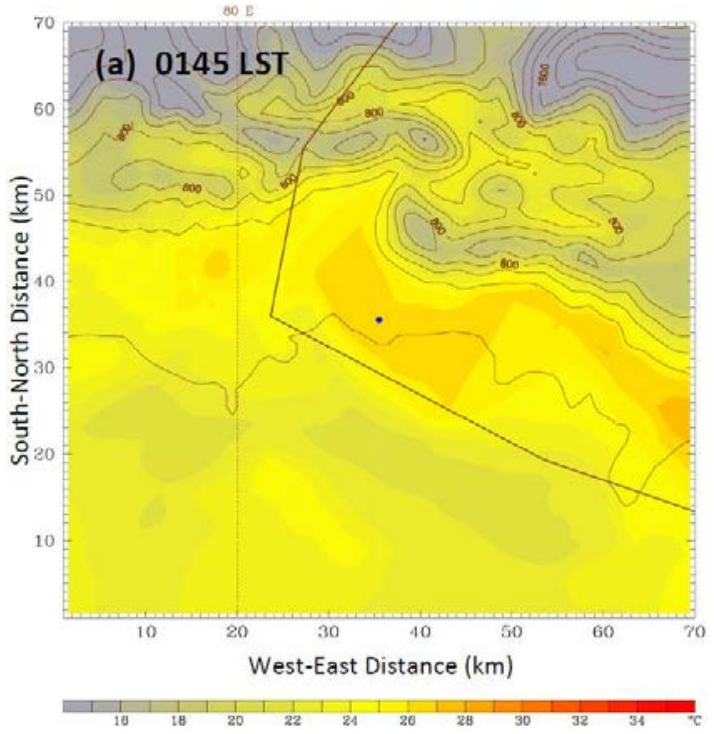

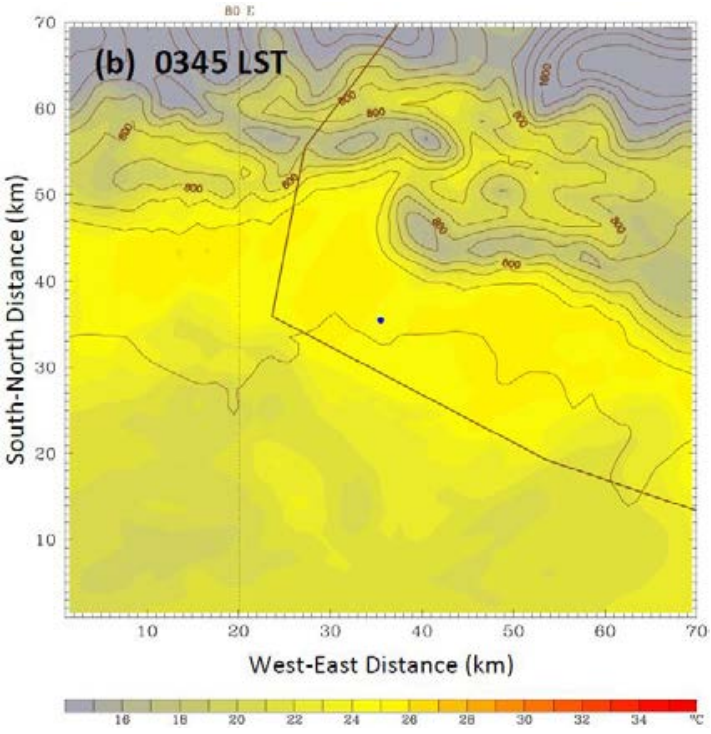
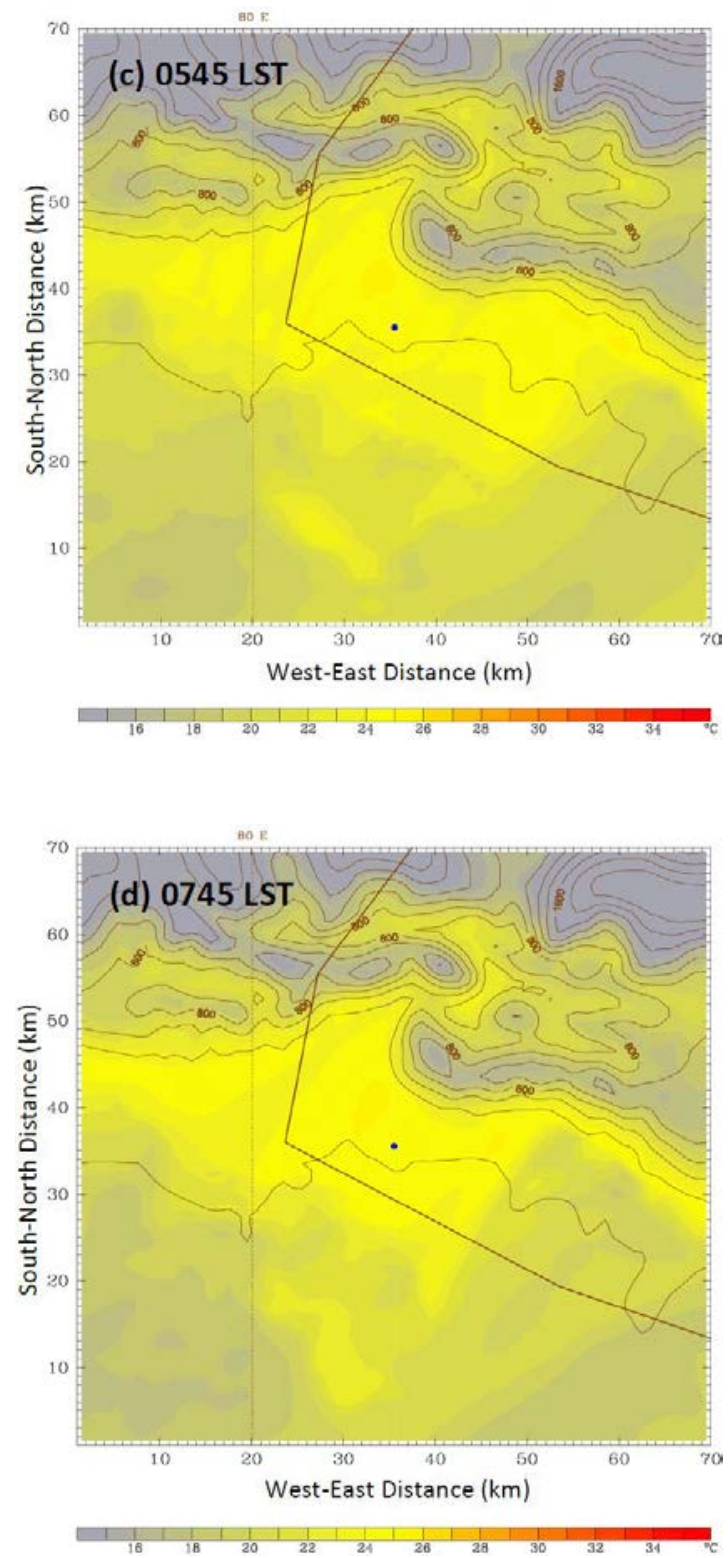

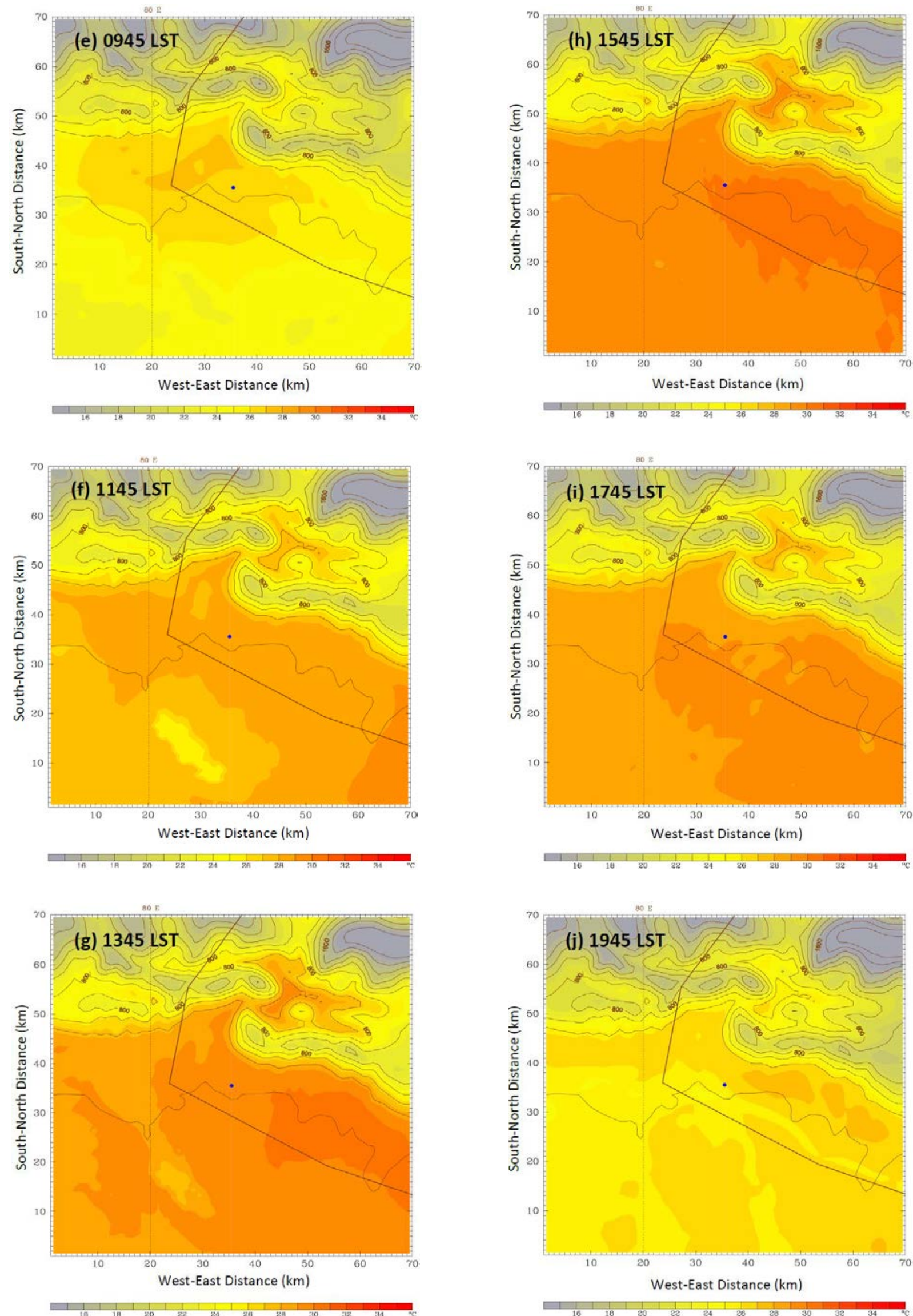

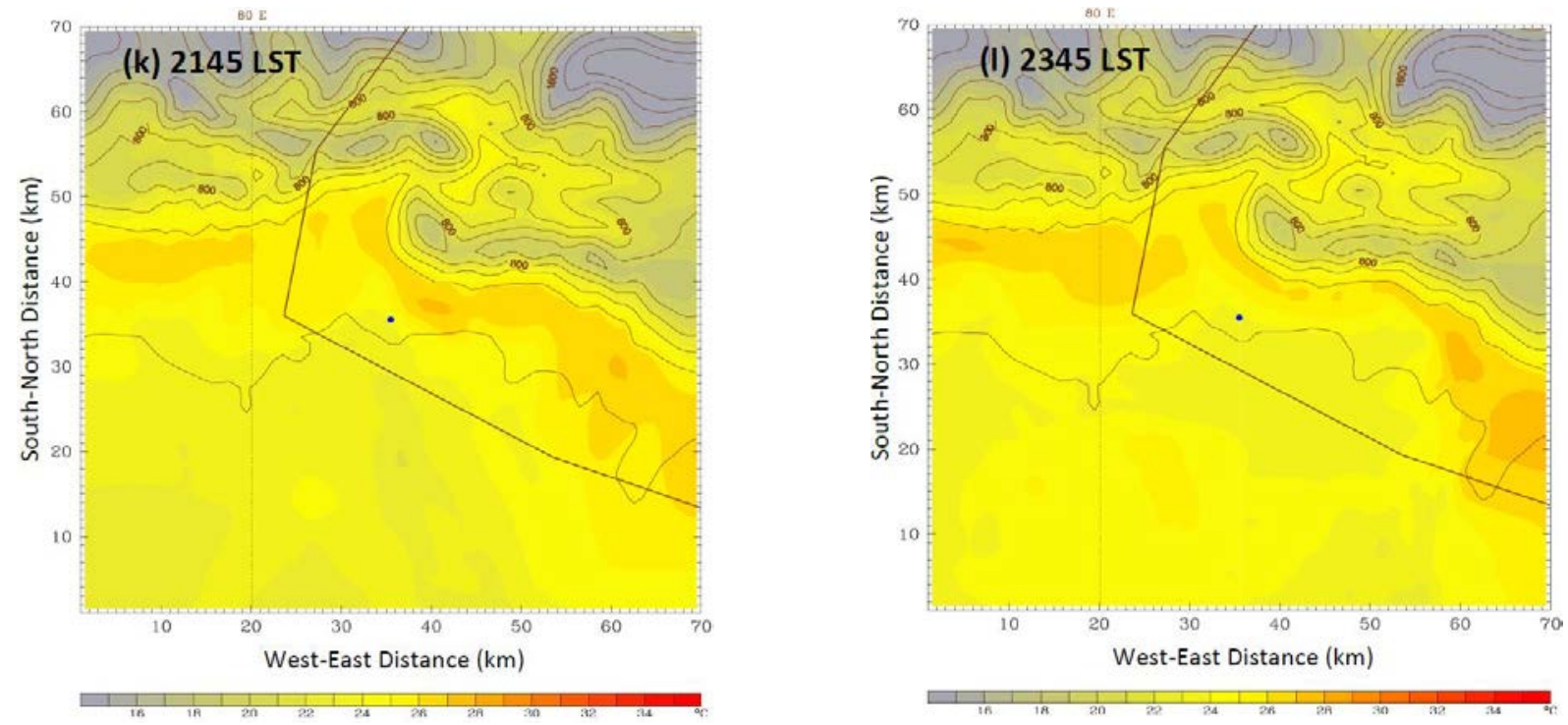
Fig. 4. The spatial and temporal evolution of temperature, superimposed with terrain contours
(at the interval of 200 meters) over FWR and its immediate surroundings.

\section{CONCLUSIONS}

The late wintertime local wind circulation characteristics and distribution of temperature over the Far-Western Region and associated areas beyond the border have been numerically simulated utilizing Weather Research and Forecasting Modeling System. The study has revealed several interesting meteorological phenomena such as significantly warmer environment prevail over plain area of Nepal compared to the Indian area. Very strong downslope wind from the northern mountainous areas swipe the plain area of Nepal that may reach just beyond the border. A strong but shallow surface inversion developed during night time over the Mahendranagar area, which broke up in the late morning. The mixed layer height over the area may reach high up to $2 \mathrm{~km}$ above the mean sea level in the afternoon. Very gentle southerly valley wind from the Indian plain area combines with the upslope wind over the mountain slope and forms very strong upvalley wind over the mountainous area of FWR. Moreover, strong diurnal periodicity in the local circulation pattern and temperature distribution has been predicted. Although, the model predictions appear to capture the general characteristics of the local wind circulations and temperature distributions over the area, they are not compared with the observation data because of the unavailability of observations. Furthermore, this is very short time simulation studies and hence a detail long term numerical and observational studies are desired to characterize the general tendencies of potential meteorological fields and hence to assess weather and climate of the region. Present findings may serve an excellent point to start further in-depth study of prevailing weather and climate of FWR of Nepal.

\section{ACKNOWLEDGEMENTS}

The University Grants Commissions of Nepal is acknowledged for granting the prestigious institutional research grants for assessing wind power potential in and around the Kathmandu valley in the year 2011. Present research was possible due to the research facilities developed at NARERL out of the project grant.

\section{REFERENCES}

Acharya, S., Neupane, S., Chapagain, C., Shrestha, R., Acharya, P., Maharjan, S. and Regmi, R.P. 2014. Early monsoon time local flow characteristics over the Hetauda valley and its implications. Journal of Institute of Science and Technology 19(2): 43-49.

Chalise, S. R. 1993. Mountain Environment in Changing Climates, edited by M. Beniston, Routledge, London and New York, pp. 382404.

Janice, L. C., Marques, C., John, M., Edward, G. P., Philip, J. R. and Kara, M. Y. 2013. WRF- 
Fire: coupled weather-wildland fire modeling with the weather research and forecasting model. Journal of Applied Meteorology and Climatolology 52: 16-38.

Jiménez, P. A. and Dudhia, J. 2012. Improving the representation of resolved and unresolved topographic effects on surface wind in the WRF model. Journal of Applied Meteorology and Climatology 51: 300-316.

Maharjan, S. 2014. Springtime meteorology of Damauli valley, Nepal: Implication for climatic comfort and environmental hygiene. Journal of Institute of Science and Technology 19(2):24-29.

Maharjan, S. and Regmi, R.P. 2014. Grid based temperature and relative humidity distribution map of the Kathmandu valley. Journal of Institute of Science and Technology 19 (1):7-13.

Michalakes, J., Chen, S., Dudhia, J., Hart, L., Klemp, J., Middlecoff, J. et al. 2001. Development of a Next Generation Regional Weather Research and Forecast Model. Developments in Teracomputing: Proceedings of the Ninth ECMWF Workshop on the Use of High Performance Computing in Meteorology. (eds.) Zwieflhofer, W. and Kreitz, N. World Scientific pp269-276.

Michalakes, J., Dudhia, J., Gill, D., Klemp, J. and Skamarock, W. 1998. Design of a nextgeneration regional weather research and forecast model towards teracomputing, World Scientific, River Edge, New Jersey pp.117-124.

Ohata, T., Higuchi, K., Zängl, G., J. Egger, and Wirth, V. 2001: Diurnal winds in the Himalayan Kali Gandaki Valley, Part II: Modelling. Monthly Weather Review 129: 1062-1080.
Regmi, R.P. 2014a. Aviation hazards over the Jomsom airport of Nepal as revealed by numerical simulation of local flows. Journal of Institute of Science and Technology 19 (1): 111-120.

Regmi, R.P. 2014b. Aviation hazards in the sky over Thada as revealed by meso-scale meteorological modeling. Journal of Institute of Science and Technology 19 (2): 65-70.

Regmi, R.P. and Maharjan, S. 2013a. Wind power density over the Kathmandu valley and its surrounding areas. Journal of Institute of Science and Technology 18 (1): 43-49.

Regmi, R.P. and Maharjan, S. 2013b. Wind energy potentials of middle hills of nepalhimalaya. World Wind Energy International Quarterly Bulletin ISSUE1:44-48.

Skamarock, W. C. and Coauthors, 2008: A description of the Advanced Research WRF version 3. NCAR Tech. Rep. TN-475+STR, National Center for Atmospheric Research, USA, $133 \mathrm{pp}$.

Song, Y., T. Zhu, X. Cai, W. Lin, and Kang, L. 2007. Glacier winds in the Rongbuk Valley, north of Mount Everest:1. Meteorological modeling with remote sensing data. Journal of Geophysical Research 112, D11101, doi:10.1029/2006JD007867.

Zängl, G., Egger, J., and Wirth, V. 2001. Diurnal winds in the Himalayan Kali Gandaki Valley, Part II: Modelling. Monthly Weather Review 129: 1062-1080.

Zhou, L., H. Zou, S. Ma, and Li, P. 2008. Study on impact of the South Asian summer monsoon on the down-valley wind on the northern slope of Mt. Everest. Geophysical Research Letters 35: L14811, doi:10.1029/2008GL034151. 